\title{
Aktualność tzw. „doktryny Giedroycia” w kontekście polityki Unii Europejskiej wobec Rosji ${ }^{1}$
}

\author{
Tomasz Kamiński, Uniwersytet Łódzki \\ ORCID ID: 0000-0003-2389-4038 \\ Marcin Frenkel, Uniwersytet Łódzki \\ ORCID ID: 0000-0003-1151-1968
}

\begin{abstract}
Streszczenie
Rosyjska interwencja w Donbasie i zabór Krymu spowodowały zasadniczą zmianę polityki Unii Europejskiej wobec jej wschodnich sąsiadów, w tym samej Rosji. Głównym celem niniejszego artykułu jest wykazanie aktualności "Doktryny Giedroycia"z w kontekście dyskusji nad nową strategią Unii Europejskiej (UE) wobec Federacji Rosyjskiej (FR). Zdaniem autorów, działania na rzecz wzrostu poziomu zamożności, stabilności i bezpieczeństwa w Europie Wschodniej tylko wtedy będą miaty charakter trwały, kiedy w samej Rosji nastąpia przemiany demokratyczne. Autokratyczna i neo-imperialna Rosja będzie przeciwdziałać wszelkim pro-zachodnim zmianom w regionie. W tym kontekście, udana transformacja FR w kraj stabilny, zamożny i demokratyczny powinna być postrzegana jako długoterminowy cel Unii Europejskiej służący bezpieczeństwu kontynentu. Wskazane jest, aby ta wizja przyświecała wszystkim politycznym aktywnościom UE na obszarze wschodniego sąsiedztwa. Oznacza to, że pomoc gospodarcza dla Ukrainy i rozwój wspótpracy z tym państwem nie powinny być celem samym w sobie. Okcydentalizację Ukrainy należy bowiem postrzegać jako jedynie początek politycznej transformacji całego regionu.
\end{abstract}

Stowa kluczowe: Polska polityka wschodnia, polityka zagraniczna Unii Europejskiej, Jerzy Giedroyc, Juliusz Mieroszewski, ULB, stosunki międzynarodowe, studia europejskie.

Pierwotna wersja tekstu prezentowana była w języku angielskim podczas zorganizowanego przez Komisję Europejską seminarium "EU A LA CARTE?", w Malmö w dniach 19-21 czerwca 2016 i ukazała się w materiałach konferencyjnych.

2 Jerzy Giedroyc był twórcą i redaktorem naczelnym „Kultury” - wydawanego w latach 1947-2000 jednego z najbardziej wpływowych pism polskiej emigracji. Stworzona kilkadziesiąt lat temu "Doktryna Giedroycia" w wielu swoich aspektach pozostaje wciąż zdumiewająco użyteczna i może wnieść wiele wartościowych treści do obecnej wewnątrz-unijnej debaty. 


\title{
The "Giedroyc's doctrine" in the context of the European Union's policy towards Russia
}

\begin{abstract}
Russian intervention in Donbas and annexation of Crimea have triggered a fundamental revision of the EU policy towards Easter neighbourhood and Russia. The main goal of this paper is to develop discussion about the EU strategy towards Russia by presenting political concept named "The Giedroyc doctrine", created by Polish intellectuals on exile, when Poland was under Soviet domination. Although created a few decades ago, some elements of this doctrine are still surprisingly relevant today and may contribute to contemporary European debate. In particular, we argue that strengthening the prosperity, stability and security in Eastern Europe is possible only when Russia transforms itself into a prosperous and democratic state. Autocratic and neo-imperial Russia undermines any major pro-Western political changes in the region. Therefore, successful transformation of Russia into stable, prosperous and democratic state should be included into the long-term vision of European politicians who intend to keep Europe secure. All political activities in the Eastern neighbourhood should be subordinated to this. It means that economic support for Ukraine and strengthening cooperation with this country should not be a goal itself. Westernization of Ukraine ought to be perceived only as a beginning of political transformation of the whole region.
\end{abstract}

Keywords: Polish eastern policy, foreign policy of the EU, Jerzy Giedroyc, Juliusz Mieroszewski, ULB, international relations, European studies.

Wydarzenia polityczne na Ukrainie, jakie miały miejsce w 2014 r. w następstwie "rewolucji godności", takie jak m.in. jednoznaczne zwycięstwo wyborcze partii umiarkowanych i porażka ruchów faszystowskich - potwierdziły, iż w tamtejszym społeczeństwie istnieje duży potencjał, który może doprowadzić do zasadniczych przemian politycznych i gospodarczych nad Dnieprem (Dragneva, Wolczuk 2015: s. 80-92, Peacock, Cordner 2016: s. 80-92).

Agresywna odpowiedź Rosji na prozachodnie zmiany na Ukrainie jest traktowana jako próba odzyskania tradycyjnej rosyjskiej strefy wpływów, lecz również można to odczytywać jako obronę samego reżimu putinowskiego. Okcydentalizacja Ukrainy podkopuje bowiem fundamenty systemu władzy w Rosji i stanowi zachętę dla rosyjskiego społeczeństwa do zakwestionowana politycznego status quo. To właśnie strach przed przeniesieniem ulicznych protestów z Ukrainy do Rosji skłonił prezydenta Władimira Putina do użycia szerokiego wachlarza środków - w tym sity zbrojnej - w celu osłabienia pozycji nowego rządu w Kijowie. Jak zauważyła Bridget Kendall, Ukraina nie mogła się stać przykładem „kolejnej Polski: zamożnej, nowoczesnej, demokratycznej i zachodniej" (Zawisza 2015). Tym samym, konflikt na Ukrainie jest nie tylko wojną o integralność terytorialną tego kraju, lecz również walką o transformację samej Rosji. Decydenci na Kremlu wydają się być tego świadomi i reagują poprzez m.in. wskrzeszenie „post-sowieckich, czy neo-sowieckich atawizmów”, aby wokół tego ogniskować poparcie własnego społeczeństwa (Judah 2014).

Konflikt rosyjsko-ukraiński stanowi czynnik destabilizujący Europę Wschodnią, a tym samym zagrażający bezpieczeństwu UE. Agresywna polityka Rosji postrzegana jest 
przez część państw członkowskich jako bezpośrednie zagrożenie dla ich państwowości. W Polsce, a przede wszystkim w państwach bałtyckich (za sprawą licznej rosyjskiej mniejszości) zaczęto obawiać się powtórzenia ukraińskiego scenariusza inwazji. Poczucie zagrożenia ze strony Rosji stało się głównym motywem stojącym za - podjętą na warszawskim szycie NATO w 2016 - decyzją o rozmieszczeniu dodatkowych wojsk Sojuszu na tzw. wschodniej flance (Gotkowska 2016).

Wydarzenia na Ukrainie skłoniły również Unię Europejską do rewizji polityki wobec Federacji Rosyjskiej (FR) i pozostałych wschodnich sąsiadów Wspólnoty. Poprzednie podejście, zakładające polityczną oraz gospodarczą transformację wschodnich sąsiadów przy nieproporcjonalnie niskich w stosunku do celów nakładach finansowych, jest uważane za błędne, szczególnie w odniesieniu do Rosji. Obecnie Unia Europejska - pomimo wewnętrznej różnicy poglądów i tendencji do przedkładania bilateralnych powiązań gospodarczych ponad wspólny interes strategiczny - poszukuje w stosunku do FR nowej długoterminowej strategii, która będzie akceptowana przez wszystkie kraje członkowskie (House of Lords European Union Committee 2015). Część kluczowych elementów tego podejścia można już zaobserwować w nowej strategii bezpieczeństwa UE (European Union 2016), a także w innych dokumentach (European Leadership Network 2016). Niemniej widoczny jest problem z wypracowaniem nowej, spójnej i kompleksowej strategii wobec Rosji. Warto postawić pytanie, na ile w polskiej myśli politycznej można wskazać idee, które mogłyby stać się cennym źródłem inspiracji intelektualnej w toczonej obecnie dyskusji? Tak zadane pytanie w sposób oczywisty jako przedmiot analizy sugeruje najważniejszy i najbardziej kompleksowy program polityki wschodniej, czyli tzw. „Doktrynę Giedroycia”.

Głównym celem niniejszego artykułu jest wykazanie aktualności koncepcji politycznych - stworzonych przez polskich intelektualistów skupionych wokół paryskiej „Kultury” - w kontekście dyskusji nad nową strategią Unii Europejskiej wobec Federacji Rosyjskiej. Idee te wywarły olbrzymi wpływ na politykę zagraniczną Polski po 1989 r. (Najder 2010). Mimo, że stworzone kilkadziesiąt lat temu, w wielu swych aspektach pozostają wciąż zdumiewająco użyteczne (Wojciechowski 2010: ss. 22-25) i mogą wnieść wiele wartościowych treści do obecnej debaty wewnątrz-unijnej.

Do opracowania niniejszego tekstu użyto metod badawczych z obszaru nauk humanistycznych: analizę dokumentów źródłowych oraz analizę genetyczną. Główną motywacją autorów była chęć zwrócenia uwagi na możliwość wykorzystania w dyskusji o założeniach polityki europejskiej wobec Rosji pewnych istniejących już koncepcji polskiej myśli politycznej. Tekst jest więc refleksją na temat intelektualnego dziedzictwa paryskiej „Kultury”. W szczególności intencją autorów było zwrócenie uwagi na fakt, że „Doktryna Giedroycia” jest w Polsce często błędnie interpretowana jako skierowana przeciw Rosji i zakładająca stworzenie „buforu” odgradzającego Europę od tego kraju.

Artykuł wpisuje się też w dyskusję na temat polityki wschodniej Unii Europejskiej. Głównym argumentem jest przywołana za paryską „Kulturą" teza, że działania na rzecz wzrostu poziomu zamożności, stabilności i bezpieczeństwa w Europie Wschodniej będą tylko wtedy miały charakter trwały, kiedy w samej Rosji nastąpią przemiany 
demokratyczne. Autokratyczna i neoimperialna Rosja zawsze będzie przeciwdziałać wszelkim prozachodnim zmianom na Ukrainie, w Białorusi, Gruzji i w innych republikach postsowieckich. W tym kontekście, udana transformacja FR w kraj stabilny, zamożny i demokratyczny powinna być postrzegana jako długoterminowy cel Unii Europejskiej, służący bezpieczeństwu kontynentu. Wskazane jest, aby ta wizja przyświecała wszystkim politycznym aktywnościom UE na obszarze wschodniego sąsiedztwa. Oznacza to, że pomoc gospodarcza dla Ukrainy i rozwój współpracy z tym państwem nie powinny być celem samym w sobie. Okcydentalizację Ukrainy należy bowiem postrzegać jako jedynie początek politycznej transformacji całego regionu.

Niniejszy artykuł składa się z trzech części. W pierwszej z nich przedstawiamy ogólny zarys politycznej strategii wobec Rosji wynikający z „Doktryny Giedroycia”. W drugiej części pokrótce przybliżamy obecną politykę UE w odniesieniu do Federacji Rosyjskiej. Na koniec staramy się przełożyć założenia „Doktryny Giedroycia” na obecną sytuację w Unii Europejskiej, skupiając się na analizie tych elementów, które wydają się być kluczowymi dla bieżącej dyskusji wokół relacji UE-Rosja.

\section{"Doktryna Giedroycia"}

Pismo „Kultura” - założone w 1946 r. w Rzymie, a wkrótce przeniesione do Maisons-Laffitte pod Paryżem - stało się najważniejszym niezależnym polskim ośrodkiem myśli politycznej okresu zimnej wojny (Berdychowska 2006). Był to niewątpliwie pewien fenomen, kiedy to mała grupa intelektualistów na emigracji stworzyła strategię, która wiele lat później została zaadoptowana jako kluczowa doktryna polityki zagranicznej państwa. Gdy w roku 1989 Tadeusz Mazowiecki - pierwszy niekomunistyczny premier Polski po II wojnie światowej - obejmował swój urząd, „Doktryna Giedroycia” stała się dla nowego rządu swoistą „mapą drogową” (Dębski 2006: s. 7). W tym okresie żadna licząca się siła polityczna nie przedstawita koncepcji alternatywnej.

Przez ostatnie dwadzieścia siedem lat rozumienie idei paryskiej „Kultury” często było niepełne lub wręcz zdeformowane. W niniejszym artykule staramy się zrekonstruować oryginalną koncepcję Giedroycia, którą można streścić w pięciu zasadniczych punktach:

1) zachowanie powojennego kształtu granic w Europie;

2) wsparcie dla niepodległości i demokratyzacji Ukrainy, Litwy i Białorusi (ULB) oraz zaprzestanie polsko-rosyjskiej rywalizacji o dominację nad tymi trzema państwami;

3) utrzymanie dobrych stosunków pomiędzy krajami Europy Wschodniej;

4) zmniejszenie napięcia w regionie - tak aby zniknęła rola Rosji jako „żandarma”, jak również jej obawa przed inwazją z Zachodu;

5) Liberalizacja Rosji.

Rosja była uważana za największe zagrożenie dla bezpieczeństwa Polski, a tym samym stanowiła kluczowy punkt odniesienia dla całej „doktryny Giedroycia”. Realizacja wyżej wymienionych punktów miała prowadzić do zmiany roli Rosji w polityce europejskiej: z czynnika destabilizującego na czynnik stabilizujący. Proces ten miał finalnie prowadzić 
do zwiększenia bezpieczeństwa Polski. Jerzy Giedroyc i jego najważniejszy publicysta - Juliusz Mieroszewski byli przekonani, że dla Polski nie ma alternatywy wobec dialogu z Rosją. W tym czasie liczne polskie środowiska emigracyjne wciąż wyczekiwały wojny nuklearnej, która by jednoznacznie rozwiązała problem zagrożenia rosyjskiego lub też snuły wizje budowy strefy buforowej oddzielającej Polskę od Rosji. Mieroszewski bezlitośnie rozwiewał te złudzenia pisząc (Mieroszewski 1966a: s. 4): „Logicznie biorąc mamy przed sobą tylko dwa rozwiązania. Albo Rosję pobić albo się z nią ułożyć. Ponieważ nie możemy jej pobić, musimy się z nią ułożyć. Na to by się z nią ułożyć musimy ją wpierw zmienić. I w tym miejscu rozpoczyna się nasz problem."

Jak zauważa Marek Kornat, zachowując swe antysowieckie stanowisko i postulaty emancypacji krajów ULB, Giedroyc nieustannie poszukiwał po rosyjskiej stronie partnerów do dialogu - do 1991 r. była to tzw. „inna Rosja” - czyli kregi opozycyjne (obrońcy praw człowieka, myśliciele, artyści), a po rozpadzie ZSRR - „nowa Rosja”, czyli już oficjalne władze nowego państwa, deklarujące - przynajmniej w latach dziewięćdziesiątych - demokratyczny kierunek przemian (Kornat 2009).

Twórcy „Kultury” byli głęboko przekonani, że jedynym sposobem uchronienia Polski i reszty Europy przed konfliktem zbrojnym jest demokratyzacja i liberalizacja Rosji. Giedroyc i Mieroszewski nigdy nie podzielali fatalistycznego przekonania, według którego Rosja może istnieć tylko jako kraj totalitarny, a jedynym możliwym partnerem do dialogu z Zachodem jest rząd nie mający demokratycznego mandatu. Takie podejście nazywali „pierwotnym błędem Dmowskiego”: „Błąd ten wynika z dwóch fałszywych przesłanek. Po pierwsze, że należy szukać porozumienia nie z narodem i społeczeństwem rosyjskim lecz z establishmentem, i po drugie, z przekonania - jakże dla Rosjan poniżającego że totalizm i imperializm są w Rosji zjawiskiem wieczystym, przeto musi się rozmawiać z carami lub z Chruszczowami, bo demokratycznego rządu w Moskwie nigdy nie będzie". (Mieroszewski 1973).

Środowisko „Kultury” wierzyło, że liberalizacja rosyjskiego ustroju jest możliwa. Obowiązkiem Zachodu jest wspieranie demokratycznej opozycji - niezależnie jak słaba jest i przełamywanie informacyjnego monopolu oficjalnych mediów. W kontaktach z Rosja państwa demokratyczne nie powinny omijać rosyjskich opozycjonistów. Syndrom oblężonej twierdzy zawsze służył do tłumienia wewnętrznego fermentu i scalania społeczeństwa wokół poczucia zagrożenia z zewnątrz. Rozbijanie blokady informacyjnej jest pierwszym krokiem wspólnoty euro-atlantyckiej do aktywnej polityki wschodniej.

Giedroyc i Mieroszewski byli przekonani, że tylko Rosjanie mogą zreformować swój kraj, a zadaniem Zachodu jest dostarczenia paliwa dla tego procesu i sprzyjającego otoczenia międzynarodowego: "Musimy od wewnątrz osiągnąć to - czegośmy nie zdołali osiągnąć z zewnątrz. Musimy stać się drożdżami przyspieszającymi proces przemian w Rosji. [...] Autentyczna zachodniość nie polega na tym, by wykorzystać pierwszą okazję dającą możność osiedlenia się w Ameryce. Zachodniość polega na tym, by kulturę zachodnią eksportować na Wschód." (Mieroszewski 1962: s. 105).

Redaktor nie miał złudzeń, że proces tworzenia w Rosji demokratycznej, pro-europejskiej partii zajmie dziesięciolecia, niemniej był pewien, że nie istnieje inna alternatywa na 
rzecz uchronienia kontynentu przed wojną. Jak podkreślał Mieroszewski, słowa są najskuteczniejszym orężem „ponieważ w ostatecznym rozrachunku zwyciężyć nie oznacza podbić lecz zjednać. Zaś zjednać oznacza przekonać." (Mieroszewski 1966b: s. 49). Dziś byśmy to nazwali przedkładaniem soft power ponad politykę siły.

Głoszony przez „Kulture” postulat dialogu z Rosją nigdy nie oznaczał unikania trudnych tematów, czy też zamazywania zbrodni przeszłości. Zaniechanie polsko-rosyjskiej rywalizacji w Europie Wschodniej nie miało również oznaczać podporządkowania jednego z partnerów drugiemu. Zarówno Giedroyc, jak i Mieroszewski podkreślali, iż żadne porozumienie z Rosją nie powinno się odbywać kosztem krajów ULB. Każdy taki zakulisowy układ byłby bowiem zarzewiem nowego konfliktu w przyszłości.

Zdaniem twórców paryskiej „Kultury”, polskie wsparcie dla niepodległości państw ULB nie jest celem samym w sobie, lecz usuwaniem potencjalnej płaszczyzny konfliktu między Rosją i Zachodem. Przez wieki tereny te były naprzemiennie obszarem ekspansji zbrojnej Polski i państwa moskiewskiego, a następnie rosyjskiego. To napięcie w relacjach z Zachodem zawsze oznaczało wzmocnienie totalitarnego charakteru władzy na Kremlu. W momencie kiedy kraje Europy Wschodniej staną się wolne i niepodległe - przyczyna konfliktu powinna zaniknąć.

Środowisko z Maisons-Laffitte było świadome, że Rosjanie postrzegają Białorusinów i Ukraińców jako narody kulturowo im bliskie. Sytuacja ta oznacza, że udana demokratyczna transformacja krajów ULB będzie stanowić zachęcający przykład dla rosyjskiego społeczeństwa. W ślad za tym liberalizacja i okcydentalizacja ustroju na Białorusi czy na Ukrainie byłaby krokiem w kierunku zmiany politycznej również w Rosji: „Wschodni Europejczycy, a przede wszystkim Polacy, mogliby odegrać poważną rolę w procesie „europeizacji” Rosji. Lecz warunkiem wstępnym w tej sprawie jest przekonać i upewnić Rosjan, a w szczególności inteligencję rosyjską, że przez europeizację rozumiemy wyłącznie likwidację totalizmu a nie likwidację Rosji jako mocarstwa." (Mieroszewski 1966b: s. 50-51).

Doktryna "Giedroyca" stanowiła i wciąż stanowi kompleksowe rozwiązanie "węzła gordyjskiego" Europy Wschodniej. Akceptacja powojennych granic usuwała płaszczyznę konfliktu pomiędzy Polską a jej sąsiadami. Tym samym Rosja traciła swą rolę regionalnego żandarma, czy też „rozjemcy”. Poparcie dla niepodległości krajów ULB miało przerwać polsko-rosyjską rywalizację o ten obszar. Zmniejszenie międzynarodowego napięcia powinno otworzyć drzwi dla demokratycznych i liberalnych zmian w samej Rosji. Ważne jest wykorzystywanie przez Zachód każdej nadarzającej się sposobności, aby ten proces wspierać - gtównie poprzez narzędzia z palety soft power. Mieroszewski pisał: „Przede wszystkim winniśmy sami wydobyć się z politycznego letargu i odzyskać naszą inicjatywę na Wschodzie. Winniśmy zerwać ze schematem, który w stosunku do Rosji dzieli Polaków na dwa przeciwstawne obozy: serwilistów i likwidatorów. Ani jedni ani drudzy nie mają żadnej szansy odzyskania inicjatywy na Wschodzie i nigdy nie zdobędą statutu partnera Rosji. [...] ani jedni ani drudzy nie są dziedzicami tradycji polskiej <<misji na Wschodzie>>. W gruncie rzeczy bowiem istotą owej misji nie był nigdy program likwidacji Rosji lecz czynny udział Polski w przebudowie i w zorganizowaniu europejskiego Wschodu." (Mieroszewski 1966a: s. 50-51). 


\section{Obecna polityka Unii Europejskiej wobec Rosji}

Przez wiele lat działania UE wobec jej wschodnich partnerów były oparte na Europejskiej Polityce Sąsiedztwa (EPS) i specjalnym "strategicznym partnerstwie" z Rosją (Börzel, Lebanidze 2015: Haukkala 2015: s. 25-40). Unia Europejska starała się wspierać polityczną oraz gospodarczą transformację i modernizację swoich wschodnich sąsiadów, ale nigdy nie przeznaczyła na ten cel wystarczająco dużych środków. Ograniczony budżet, niezdecydowanie, brak spójnego stanowiska przyczyniły się do fiaska polityki wschodniej i zakwestionowały pozycję UE, jako siły normatywnej oddziałującej na swe najbliższe otoczenie (Nielsen, Vilson 2014). Szczególnie jest to widoczne w przypadku Rosji, gdzie pomimo podpisanych porozumień - w tym ostatniego „Partnerstwa dla Modernizacji (P4M)" z czerwca 2010 r. - relacje ulegały pogorszeniu, a żadna "modernizacja” nie miała miejsca (Romanowa, Pavlova: 2014: s. 499-517).

Formalnie, podstawą prawną relacji unijno-rosyjskich jest Porozumienie o Partnerstwie i Współpracy (PCA), które weszło w życie w 1997 (Agreement on Partnership and Cooperation 1997). Porozumienie to, wraz z dodatkowymi umowami sektorowymi (obejmującymi między innymi takie obszary jak edukacja, nauka i technologia, środowisko czy transport), ustanawiaja strukturę regularnych konsultacji i spotkań politycznych na różnych szczeblach.

Agresywna polityka Rosji wobec Ukrainy poddała w wątpliwość podstawy polityki unijnej, wedle których państwo to postrzegano jako "strategicznego partnera" (Gotev 2016). Uległa zmianie również „wielka narracja stosunków unijno-rosyjskich”, która obejmowała nieustannie powtarzane próby "konstruktywnego zaangażowania”, mające na celu „związanie” Rosji z Europą i jej kluczowymi instytucjami (Haukkala 2015: s. 25-40). Wydarzenia na Ukrainie, takie jak aneksja Krymu, czy interwencja zbrojna w Donbasie, zmusity UE do podjęcia niecodziennych działań wymierzonych w Rosję.

Od początku ukraińskiego kryzysu w 2014 r. unijna polityka wobec Rosji opierała się na sankcjach gospodarczych i zdecydowanym poparciu dla integralności terytorialnej Ukrainy. Zawieszono również wspótprace polityczną w ramach wielu dialogów sektorowych z Federacją Rosyjską. Polityczny konsensus państw członkowskich UE - mimo, iż wydawał się być bardzo kruchym - okazał się być zdumiewająco trwały. Co więcej, ta polityka do pewnego stopnia może się okazać sukcesem, bowiem ofensywa rosyjska została zatrzymana, a proeuropejski wybór Ukrainy został potwierdzony przez kompleksową umowę o wolnym handlu (DCFTA), która weszła w życie w styczniu 2016 r.

Sankcje gospodarcze w powiązaniu ze spadającymi cenami ropy wydają się być wyjątkowo niekorzystne dla rosyjskiego budżetu. Jednym z przejawów skuteczności sankcji jest spadająca wartość rubla (z 33 rubli za dolara w czerwcu 2014 r. do 65 rubli dwa lata później). Tak drastyczny spadek wartości rubla prowadzi do wzrostu inflacji i kurczenia się rezerw walutowych. Dla przykładu, jeszcze w 2009 roku Rosja miała odłożoną w ramach swoich państwowych funduszy majątkowych równowartość 20\% PKB. W 2017 roku rezerwy te stanowiły około 6\% (Kamiński 2018: s. 206-207). Międzynarodowy Fundusz Walutowy w raporcie z 2015 roku oceniał, że sankcje będą 
kosztowały Rosję około 9\% PKB na przestrzeni 10-15 lat (International Monetary Fund 2015). W dłuższej perspektywie powinno to doprowadzić do ograniczenia rosyjskich zdolności wojskowych i osłabienia podstaw ekonomicznych państwa, a co za tym idzie również aktualnego układu władzy.

Nie ulega jednak wątpliwości, że polityka sankcji stanowi krótkookresową odpowiedż, a nie rozwiązanie na dłuższy czas. Oznacza to, że UE stoi przed koniecznością opracowania nowej strategii wobec Rosji, z jasno określonymi celami i klarowną wizja przysztych relacji.

Pomimo oficjalnie deklarowanej jedności (Council of the European Union 2016), kraje członkowskie UE różni stosunek do Rosji. Z racji limitów objętościowych niniejszego artykułu, ograniczymy się do wymienienia tu tylko dwóch skrajnych postaw: polityki ustępstw i zaangażowania oraz polityki powstrzymywania. To pierwsze podejście reprezentuja państwa (takie jak np. Grecja, Wegry, Austria czy Włochy), które mają bliskie związki gospodarcze z Rosją, albo znajdują się na tyle daleko od wschodniej granicy UE, iż agresywne zachowania tego państwa nie stanowia dlań wprost zagrożenia. Te kraje, mniej lub bardziej otwarcie, krytykują politykę sankcji i domagają się normalizacji stosunków z Rosją. Drugie podejście charakterystyczne jest między innymi dla Polski i Litwy - czyli krajów, które postrzegają Rosję jako bezpośrednie zagrożenie militarne i które uważają, że zniesienie sankcji jest możliwe wyłącznie po odzyskaniu przez Ukrainę kontroli nad swoja wschodnią granicą. Większość państw członkowskich lokuje się pomiędzy tymi dwoma biegunami (Liik 2018).

Z tego też powodu, oficjalne stanowisko UE, zaprezentowane między innymi w Europejskiej Strategii Bezpieczeństwa jest raczej umiarkowane i zawiera zarówno elementy polityki „angażowania”, jak i „powstrzymywania”. W krótkim fragmencie poświęconym Rosji jest ona nazwana „strategicznym wyzwaniem", a nie partnerem, ale widoczne jest również zaproszenie do współpracy (wezwanie do „selektywnego angażowania"): „Zarządzanie relacjami z Rosją stanowi kluczowe wyzwanie strategiczne. Konsekwentne i wspólne stanowisko musi pozostać podstawą polityki UE wobec Rosji. Jakiekolwiek znaczące zmiany w stosunkach pomiędzy Unię Europejską a Federacją Rosyjską muszą być oparte na całkowitej zgodności z prawem międzynarodowym i zasadami tworzącymi europejski system bezpieczeństwa - wliczając w to Akt Końcowy KBWE i Kartę Paryską. Nie zamierzamy uznać nielegalnego zaboru Krymu przez Rosję, ani zaakceptować prowadzonej przez nią destabilizacji wschodniej Ukrainy. Będziemy działać na rzecz wzmocnienia UE, poprawy zdolności obronnych naszych wschodnich sąsiadów i wspierać ich prawo do samodzielnego określenia się wobec UE [...] Prócz wspomnianych zagadnień dotyczących polityki zagranicznej nad którymi obecnie pracujemy, dopuszczamy również selektywne angażowanie Rosji w rozwiązywanie problemów dotyczących zmian klimatycznych, Arktyki, bezpieczeństwa żeglugi, edukacji, badań naukowych i współpracy trans-granicznej. To angażowanie Rosji powinno obejmować również rozwój więzi pomiędzy społeczeństwami poprzez ułatwienia w podróżowaniu dla studentów, działaczy społecznych i przedsiębiorców." (European Union 2016). 
W innej formie to podejście zostało zaprezentowane przez Radę Unii Europejskiej, która zgodziła się w marcu 2016 r. w zakresie pięciu zasad przyświecających unijnej polityce wobec Rosji (Council of the European Union 2016):

1) wprowadzenie w życie postanowień porozumienia w Mińsku, jako warunek brzegowy dla jakiekolwiek zasadniczej zmiany w stanowisku UE wobec Rosji;

2) wzmocnienie relacji pomiędzy UE a jej wschodnimi sąsiadami i pozostałymi partnerami - zwłaszcza z Azji Środkowej;

3) wzmocnienie zdolności skutecznego reagowania UE w obszarze bezpieczeństwa energetycznego, zagrożeń hybrydowych i komunikacji strategicznej;

4) wsparcie dla kontaktów międzyludzkich i rozwoju społeczeństwa obywatelskiego w Rosji.

Oba ww. dokumenty prezentują raczej spójne stanowisko, które kładzie nacisk z jednej strony na sprzeciw wobec agresywnej polityki rosyjskiej, a z drugiej strony akcentuje istniejące pomiędzy partnerami współzależności, które wymuszają współpracę w wielu dziedzinach. To umiarkowane i wyważone stanowisko zajęte przez UE jest dobrym punktem wyjścia dla rozwinięcia strategicznej wizji relacji z Rosją. W następnej części artykutu zaproponujemy zaadoptowanie wybranych elementów „Doktryny Giedroycia” do współczesnej polityki unijnej wobec Federacji Rosyjskiej.

\section{Doktryna Giedroycia a dtugookresowe cele polityki wschodniej UE}

Podstawowy długookresowy cel polityki zagranicznej Unii Europejskiej skierowanej do wschodnich sąsiadów można streścić jako działanie na rzecz wzrostu poziomu zamożności, stabilności i bezpieczeństwa w Europie Wschodniej. Jak dotychczas, Unia Europejska starała się to zadanie realizować poprzez inspirowanie i wspieranie politycznej i gospodarczej transformacji krajów wschodnioeuropejskich. Założenia te były słuszne i raczej nie wzbudzały kontrowersji. Niestety obecną sytuację na wschodniej granicy UE trudno nazwać stabilną i bezpieczną, a kraje sąsiedzkie dalekie są od zamożności. Głównym powodem tego stanu rzeczy jest długofalowa, konsekwentna i agresywna polityka Rosji, który stara się „wykoleić” każdą unijną inicjatywę w regionie (Saari 2014: s. 50-66). Założenie, że również w przyszłości Rosja będzie posiadać polityczne, wojskowe i gospodarcze środki destabilizacji państw post-sowieckich, znajdujących się w szarej strefie pomiędzy Wschodem a Zachodem, jest dobrym punktem wyjścia do zastosowania „Doktryny Giedroycia”, która notabene została stworzona w czasach, kiedy Rosja była znacznie silniejsza niż jest dzisiaj.

Analizując główne elementy doktryny, można wskazać, iż co najmniej pięć z nich może mieć zastosowanie w unijnej polityce wschodniej:

\section{1) Transformacja Rosji jest warunkiem sine qua non}

Działania UE na rzecz wzrostu poziomu zamożności, stabilności i bezpieczeństwa w Europie Wschodniej będą tylko wtedy miały charakter trwały, kiedy w samej Rosji nastapia przemiany demokratyczne. Autokratyczna i neoimperialna Rosja 
będzie przeciwdziałać wszelkim prozachodnim zmianom w regionie. W tym kontekście, udana transformacja Federacji Rosyjskiej w kraj stabilny, zamożny i demokratyczny powinna być postrzegana jako długoterminowy cel Unii Europejskiej, służący bezpieczeństwu kontynentu. Mając to na uwadze, UE nie może pomijać Rosji w działaniach promujących przemiany demokratyczne i strukturalne przemiany gospodarcze krajów Europy Wschodniej.

\section{2) Normalizacja jako cel gtówny}

Celem polityki wschodniej UE powinno być budowanie dobrych relacji z Rosją. Rozwój wzajemnych stosunków gospodarczych i politycznych leży w interesie obu stron. Tym samym, należy unikać zaklętego kręgu narastającej konfrontacji. Normalizacja relacji powinna więc zawsze zajmować wysoką pozycję na liście unijnych priorytetów, a w konsekwencji niemalże wszystkie polityczne przedsięwzięcia na obszarze wschodniego sąsiedztwa należy temu podporządkować. Niemniej nie powinno się tego utożsamiać z polityką „Najpierw Rosja” (ang. Russia first), która już dowiodła swojej nieskuteczności. Proponujemy tu raczej hasło „Również Rosja", co ma akcentować konieczność politycznej zmiany i w tym kraju tak, aby zapewnić stabilność całego regionu.

\section{3) Niepodległość i terytorialna integralność państw postsowieckich nie może} podlegać dyskusji

Pełna akceptacja powojennych granic w Europie i niepodległość państw byłego ZSRR nie może być przedmiotem dyskusji z Rosją, lecz musi być traktowana jako warunek wstępny jakichkolwiek układów z tym państwem. W ślad za tym, unijni liderzy powinni się sprzeciwiać siłowym próbom przesunięcia ukraińskich granic. Rosja nie może mieć żadnych złudzeń, że jakakolwiek zmiana granic spotka się z akceptacją społeczności międzynarodowej.

\section{4) Ukraina jako pomost, a nie mur}

Europa nie powinna budować strefy buforowej w postaci powiązanych z Zachodem byłych republik sowieckich, które będą separować Rosję od reszty kontynentu. Przeciwnie, wsparcie dla zmian na Ukrainie i współpraca z tym krajem nie powinna być celem samym w sobie, lecz zaczynem dla politycznej transformacji całego regionu. Dogłębna liberalizacja ustroju na Ukrainie stworzy szansę budowy „pomostu do Moskwy”, który uchroni Rosję przed międzynarodową izolacją i wzmocnieniem autokratycznego reżimu Putina. Zatem silna polityczna i gospodarcza pomoc dla Ukrainy w najbliższych latach powinna być podstawowym elementem unijnej polityki wschodniej. Unia Europejska powinna nalegać na pełne wprowadzenie w życie postanowień Umowy Stowarzyszeniowej i domagać się głębokich reform politycznych na Ukrainie, jak również zapewniać techniczne i finansowe wsparcie dla tych procesów. Sukces w reformowaniu tego kraju mógłby stanowić wzór dla całego regionu, w tym dla Rosji.

\section{5) Tylko Rosjanie mogą zmienić Rosję}

Ustanawiając długofalowy cel, jakim jest transformacja Rosji, Unia Europejska powinna być w pełni świadoma pomocniczego charakteru swej roli. Proces 
transformacji musi być zainicjowany i przeprowadzony przez samych Rosjan. Niemniej świadomość istniejących ograniczeń i przeszkód nie może stanowić usprawiedliwienia dla polityki pasywnej i apatycznej.

Prozachodnia rewolucja na Ukrainie dowiodła, że unijna moc przyciagania nie jest mitem, lecz realnym narzędziem politycznym. „Europejskie marzenie” skłoniło tysiące Ukraińców do wyjścia na ulice w proteście przeciw władzom, które odrzuciły umowe stowarzyszeniową z UE. Wielu z tych demonstrantów zginęło w starciach z milicją na ulicach Kijowa lub w walkach z rosyjską inwazją w Donbasie. Pierwszy raz w historii tak wiele osób poświęciło swoje życie w imię idei europejskiej integracji. To jest też powód, dla którego Unii Europejska jako całość, ale także poszczególne kraje członkowskie, nie powinny rezygnować z rozwoju kontaktów z rosyjskim społeczeństwem. Kontakty międzyludzkie poprzez promocję europejskiej kultury, programów wymiany studenckiej, współpracy naukowej itp. mogą być w dłuższym okresie bardzo przydatne w osiąganiu celów unijnej polityki wschodniej.

Wydaje się, że Unia zdaje sobie z tego sprawę, starając się aby polityka sankcji i wycofywania się z niektórych dialogów sektorowych nie wpłynęła negatywnie na relacje na poziomie P2P (people-to-people). Dlatego też zawieszenie dialogu nie objęło współpracy edukacyjnej, naukowej, czy kontaktów transgranicznych.

Nie oznacza to jednak, że pogorszenie relacji politycznych nie wpłynęło na kontakty międzyludzkie. Jako przykład można wskazać współpracę naukową, realizowaną w ramach sztandarowego unijnego programu Horyzont 2020, a wcześniej w ramach tzw. Programów Ramowych. W trakcie pierwszych dwóch lat funkcjonowania programu Horyzont 2020 (2014-2015) liczba rosyjskich naukowców zaangażowanych we wspólne projekty z partnerami unijnymi drastycznie spadła w porównaniu z wcześniejszym okresem. Spowodowane to było, jak przyznaje Komisja Europejska, zmianą reguł finansowania współpracy z Rosją na mniej korzystną dla naukowców z tego kraju, ale także przekonaniem wielu europejskich projektodawców, że współpraca z partnerami rosyjskimi nie byłaby mile widziana (European Commission 2017). Przykład ten obrazuje, jak trudno jest oddzielić relacje na poziomie strategicznym od wspótpracy na najniższych szczeblach kontaktów, choć warto odnotować, że wyraźnie widać taką wole w Komisji Europejskiej.

Jerzy Giedroyc nigdy nie twierdzit, że jego idee strategiczne są tatwe do wdrożenia, czy też szybko przyniosą sukces. Przeciwnie, stawiał on na ambitne plany długofalowe. Wydaje się, że takie połączenie przyziemnego podejścia z dalekosiężnym planowaniem jest jedyną kombinacją, która może przynieść sukces. Żaden ambitny pomysł nie zostanie w polityce wschodniej zrealizowany szybko - mówimy tu raczej o dekadach niż latach, niemniej nie powinno to nikogo zniechęcać do działania. Być może jest to najcenniejsza lekcja, jaką może dać Unii Europejskiej Jerzy Giedroyc.

\section{Wnioski}

Polska dyplomacja zwykła podkreślać swą ekspercką rolę w zagadnieniach dotyczących obszaru postsowieckiego. Jakkolwiek do pewnego stopnia jest to uzasadnione, to 
wiele polskich pomysłów - za wyjątkiem m.in. Partnerstwa Wschodniego - było etykietowane przez naszych zachodnich partnerów jako inicjatywy antyrosyjskie, a nasteppnie odrzucane. Tymczasem, Jerzy Giedroyc, którego żona, notabene, była rosyjską aktorka, znał Rosję bardzo dobrze i lubił Rosjan. Można nawet powiedzieć, że był rusofilem, więc trudno jego koncepcje nazywać antyrosyjskimi. W swej autobiografii Redaktor podkreślak: „Zawsze pasjonowała mnie literatura rosyjska. Czytałem po rosyjsku prawie tyle co po polsku, tzn. bardzo dużo [...] Wolę poezję rosyjską od poezji polskiej." (Giedroyc 2006: s. 16).

Również Juliusz Mieroszewski wielokrotnie krytykował poglądy rusofobiczne: „Nie zamierzam dyskutować z ludźmi, których program wschodni składa się z emocji, kompleksów i uprzedzeń. Ci panowie, którzy głoszą, że wszystko co rosyjskie jest złe i godne pogardy, stanowia problem dla psychiatrów a nie dla polityka." (Mieroszewski 1973: s. 69).

Londyński publicysta "Kultury" nie raz demonstrował też swój sprzeciw wobec fatalistycznego przekonania, że Rosja jest nieodwracalnie skazana na ustrój imperialistyczny, niedemokratyczny i agresywny wobec sąsiadów. Twórcy „Kultury” postrzegali ZSRR jako zjawisko - mimo wszystko - przejściowe. Obowiązkiem polskich elit miało być przygotowanie się na moment, w którym po rozpadzie ZSRR pojawi się konieczność dialogu z demokratyzującą się Rosją. Skoncentrowanie się na niekończących się rachunkach strat i wzajemnych oskarżeń byłoby drogą donikąd. Potrzebna była pragmatyczna polityka dialogu nastawionego na rozwiązywanie konkretnych spraw, a nie utwierdzanie się w poczuciu cywilizacyjnej wyższości i roli przedmurza cywilizacji europejskiej. Zdaniem Mieroszewskiego, XIX wiek dowiódł, że Europa może się dynamicznie rozwijać bez Polski - to my jesteśmy dodatkiem do reszty kontynentu, a nie odwrotnie.

Dziś, kiedy jesteśmy świadkami gwałtownego pogorszenia stosunków polsko-rosyjskich i unijno-rosyjskich, idee paryskiej „Kultury” powstałe w okresie zimnej wojny, wydają się być zdumiewająco aktualne. Unia Europejska nie może już kontynuować dotychczasowej, miałkiej, letniej i nieskutecznej polityki wobec Rosji (Haukkala 2015), lecz powinna szukać nowych rozwiązań. Unijni stratedzy mogliby sięgnąć do założeń ambitnej „doktryny Giedroycia”, dopasowując je do aktualnego europejskiego kontekstu politycznego. Spuścizna paryskiej „Kultury” może stanowić dobrą podstawe dla planu wielkiej transformacji wschodniego sąsiedztwa w zamożny, stabilny i bezpieczny obszar, co jest w pełni zgodne z długofalowymi interesami, jak również z liberalnymi zasadami stanowiącymi fundament UE.

Warto odnotować, że już teraz niektóre elementy unijnej polityki wobec Rosji - takie jak potępienie zmian granicznych w Europie czy akcentowanie roli współpracy międzynarodowej na poziomie międzyludzkim - są zasadniczo zbieżne z „doktryną Giedroycia”.

Jako potencjalny wkład idei paryskiej „Kultury” w politykę zagraniczną UE widzimy przede wszystkim trzy elementy. Po pierwsze, założenie, że nie jest możliwa stabilizacja regionu bez transformacji ustrojowej w samej Rosji. Po drugie, przekonanie, że udana liberalizacja Ukrainy może stworzyć szansę na budowę „pomostu do Rosji”, który uchroni ten kraj przed izolacją i wzmocnieniem autokratycznego charakteru putinowskiego reżimu. Po trzecie, wieloaspektowa wspótpraca ze społeczeństwem rosyjskim powinna być rozwijana nawet w sytuacji złych relacji politycznych. 
Tomasz Kamiński - dr hab. nauk humanistycznych, adiunkt w Katedrze Studiów Azjatyckich, na Wydziale Studiów Międzynarodowych i Politologicznych Uniwersytetu Łódzkiego. Politolog, którego zainteresowania badawcze koncentrują się wokót instrumentów polityki zagranicznej, polityki Unii Europejskiej wobec Chin, państwowych funduszy majątkowych oraz paradyplomacji. Kierownik projektów finansowanych przez Komisję Europejską (Horyzont 2020, Jean Monnet) oraz Narodowe Centrum Nauki (OPUS). Stały współpracownik czasopisma „Liberté!". Pasjonat innowacyjnych metod nauczania i wykorzystywania gier w edukacji. Twórca edukacyjnej gry komputerowej „Zarządzenie projektami unijnymi”. Stypendysta w EUI we Florencji. Autor książek "Sypiając ze smokiem. Polityka Unii Europejskiej wobec Chin” oraz "Pieniądze w służbie dyplomacji. Państwowe fundusze majątkowe jako narzędzie polityki zagranicznej".

Adres e-mail: tomasz.kaminski@uni.lodz.pl

Tomasz Kaminiski - Ph.D., political scientist, assistant professor at the Faculty of International and Political Studies, University of Lodz (Poland). His research activities are concentrated on instruments of foreign policy, the EU policy towards China, Sovereign Wealth Funds and paradiplomacy. He has worked in numerous research projects funded by the European Commission (Horizon 2020, Jean Monnet Module) or the Polish National Science Centre. A regular contributor to the magazine "Liberté!". Passionate about innovative teaching and using games in education. He has been engaged in development of educational computer game about the project management. Recently he has co-authored a book "Paradiplomacy in Asia".

E-mail: tomasz.kaminski@uni.lodz.pl

Marcin Frenkel - mgr, doktorant na Wydziale Studiów Międzynarodowych i Politologicznych Uniwersytetu Łódzkiego. Zainteresowania naukowe: polska polityka wschodnia, polityka zagraniczna USA, międzynarodowe stosunki polityczne, cyfryzacja gospodarki światowej. Członek zespołu redakcyjnego czasopisma „Liberté!". Współautor eksperckiego raportu "Digital New Deal for V4: How do we stand with new technologies?", analizującego przygotowanie państw Grupy Wyszehradzkiej do wyzwań Gospodarki 4.o.

Adres e-mail: marcinfrenkel@wp.pl

Marcin Frenkel - a PhD candidate at the Faculty of International and Political Studies, Univesity of Łodż (Poland). His research interests lie in the field of Polish foreign policy, the US foreign policy, international political relations and digitalisation of the world economy. Recently he has co-authored experts report "Digital New Deal for V4: How do we stand with new technologies?".

E-mail: marcinfrenkel@wp.pl

\section{$\Theta$ Bibliografia}

AGREEMENT ON PARTNERSHIP AND COOPERATION establishing a partnership between the European Communities and their Member States, of one part, and the Russian Federation, of the other part, „Official Journal", L 327 , 28/11/1997 P. 0003 - 0069.

BERDYCHOWSKA Bogumita (2006), Ukraina w życiu Jerzego Giedroycia i na tamach paryskiej „Kultury”, "Culture.pl”, http://culture.pl/pl/artykul/ukraina-w-zyciu-jerzego-giedroycia-i-na-lamachparyskiej-kultury (05.04.2018). 
BÖRZEL Tanja, LEBANIDZE Bidzina (2015), European Neighbourhood Policy at the Crossroads: Evaluating the Past to Shape the Future, "Maxcap Working Paper Series", nr 12.

COUNCIL OF THE EUROPEAN UNION (2016), Outcome Of The Council Meeting, 3457th Council meeting, "Foreign Affairs", Brussels (14.03.2016).

DEBSSKI Sławomir (2006), Polityka wschodnia mit i doktryna, „Polski Przegląd Dyplomatyczny”, nr 3 (31). DRAGNEVA Rilka., WOLCZUK Kataryna (2015), Ukraine between the EU and Russia. The Integration Challenge, London.

EUROPEAN COMMISSION (2017), Roadmap for EU-Russia S\&T Cooperation, Brussels.

EUROPEAN LEADERSHIP NETWORK (2016), What is the future for EU-Russia relations? A survey of European Leadership Network members for the EU's Global Strategy on foreign and security policy, May.

EUROPEAN UNION (2016), Shared Vision, Common Action: A Stronger Europe A Global Strategy for the European Union's Foreign And Security Policy, https://europa.eu/globalstrategy/en (05.04.2018)

INTERNATIONAL MONETARY FUND (2015), Russian Federation, IMF Country Report No. 15/211.

JUDAH Ben (2014), Putin's Coup. How the Russian leader used the Ukraine crisis to consolidate his dictatorship, „Politico", http://wwwwpolitico.com/magazine/story/2014/10/vladimir-putinscoup-112025.html\#ixzz3HRLKZf3l (05.04.2018)

GIEDROYC Jerzy (2006), Autobiografia na cztery rece, Warszawa.

GOTKOWSKA Justyna (2016), NATO na wschodniej flance - nowy paradygmat, "Analizy OSW”, https://www.osw.waw.pl/pl/publikacje/analizy/2016-07-13/nato-na-wschodniej-flance-nowy-paradygmat (05.04.2018)

HAUKKALA Hiski (2015), From Cooperative to Contested Europe? The Conflict in Ukraine as a Culmination of a Long-Term Crisis in EU-Russia Relations, "Journal of Contemporary European Studies", Vol. 23, Issue 1.

HOUSE OF LORDS European Union Committee (2015), The EU and Russia: Before and Beyond the Crisis in Ukriane, 6th Report of Session 2014-2015, HL Paper 115.

KAMIŃSKI Tomasz (2018), Pieniadze w stużbie dyplomacji. Państwowe fundusze majatkowe jako narzedzie polityki zagranicznej Rosji, Wydawnictwo Uniwersytetu Łódzkiego.

KORNAT Marek (2009), Realizm środków, idealizm wizji. O geopolitycznej wizji Jerzego Giedrojcia i Juliusza Mieroszewskiego, w: Jacek Kłoczkowski (red.), Przeklęte miejsce Europy? Tradycje polskiej geopolityki, Kraków.

MIEROSZEWSKI Juliusz (1962), Na ruinach przedmurza, „Kultura”, nr 5 (175).

MIEROSZEWSKI Juliusz (1966a), Tysiac lat i co dalej, „Kultura”, nr 7-8 (225-226).

MIEROSZEWSKI Juliusz (1966b), ABC polityki, „Kultura”, nr 4 (222).

MIEROSZEWSKI Juliusz (1973), Polska „Ostpolitik”, „Kultura”, nr 6 (309).

NAJDER Zbigniew (2010), Doktryna ULB - koncepcja Giedroycia i Mieroszewskiego w XXI wieku, „Komentarz Międzynarodowy Puławskiego", maj. http://wwww.pulaski.pl/images/publikacje/ $\mathrm{kmp} / 2010 /$ Pulaski_Policy_Papers_No_11_10.pdf

NIELSEN Kristian, VILSON Maili (2014), The Eastern Partnership: Soft Power Strategy or Policy Failure? "European Foreign Affairs Review", Volume 19, Issue 2.

PEACOCK Robert, CORDNER Gary (2016) "Shock Therapy" in Ukraine: A Radical Approach to PostSoviet Police Reform, Public Administration and Development, Volume 36, Issue 2. 
ROMANOVA Tatiana, PAVLOVA Elena (2014), What Modernisation? The Case of Russian Partnerships for Modernisation with the European Union and Its Member States, "Journal of Contemporary European Studies", Volume 22, Number 4.

SAARI Sinikukka (2014), Russia's Post-Orange Revolution Strategies to Increase Its Influence in Former Soviet Republics: Public Diplomacy Po russkii. "Europe-Asia Studies", Volume 66, Issue 1.

LIIK Kadri (2018), Winning the normative war with Russia: An EU-Russia Power Audit, European Council on Foreign Relations.

WOJCIECHOWSKI Marcin (2010), Co po Giedroyciu? Giedroyc!, „Nowa Europa Wschodnia”, nr 1.

ZAWISZA Tom (2015), Bridget Kendall: Is Putin afraid of a Russian Maidan?, "Cambridge Globalist", http://cambridgeglobalist.org/2015/05/22/bridget-kendall-is-putin-afraid-russian-maidan/ (05.04.2018) 